\title{
移行上皮癌を抗原として得られた上皮特異的
}

\section{モノクローナル抗体 EH14の検討}

\begin{tabular}{|c|c|c|c|c|}
\hline \multicolumn{5}{|c|}{ (土1 } \\
\hline 織田 & 英昭 & 濱田 & 斉 & 骨嶋 \\
\hline 横山 & 雅好 & 岩田 & 英信 & 竹内 \\
\hline
\end{tabular}

\section{STUDY OF A MONOCLONAL ANTIBODY AGAINST NEW EPITHELIAL MEMBRANE ANTIGENS ON TRANSITIONAL CELL CARCINOMA}

\author{
Hideaki Oda, Hitoshi Hamada, Shinji Nabeshima, Masayoshi Yokoyama, \\ Hidenobu Iwata and Masafumi Takeuchi \\ Department of Urology, Ehime University School of Medicine
}

(Director: Prof. M. Takeuchi)

Immunizing mice with a transitional cell cancer (TCC) tissue in the renal pelvis, we produced a monoclonal antibody (EH14) against new epithelial antigens. After the mice were immunized repeatedly, their splenic cells were harvested and fused with NS/1 myeloma cells. The normal kidney tissue of the same patient was used on Dot blots to select the hybridoma. A a result, one hybridoma whose antibody (EH14) reacted very strongly with TCC but only faintly with normal kidney tissue or normal bladder mucosa was obtained. On immunohistochemistry, EH14 stained all of the 29 TCC tissues. EH14 also stained uterus cancer (7/7) and gastric cancer $(6 / 6)$ as well as the normal squamous cell and many types of the normal epithelium. All of the lymphnodes containing metastatic bladder cancer were strongly stained with EH14. EH14, however, did not stain interstitial tissues, muscles and sarcomas. The molecular weight of the antigen recognized by EH14 was $14 \mathrm{KD}$ and $28 \mathrm{KD}$ on Western blot analysis, and the antigen was stable with formalin or ethanol. The antigen was not the same as that reported previously, and may be useful as a histological marker of TCC.

Key words: monoclonal antibody, transitonal cell carcinoma, epithelial membrane antigen

\footnotetext{
要旨：今回われわれは，腎盘移行上皮癌を抗原とし，上皮特異的抗原を認識するモノクローナル抗体 EH14（IgM. kappa）を得た。免疫した BALB/c マウス脾細胞とマウスミエローマ細胞（NS/1）を細 胞融合させ，スクリーニングは Dot ELISA にて行い，移行上皮癌に反応し，同一患者の正常腎組織には 反応しない抗体を得た。免疫組織学的検討では, EH14は29例の移行上皮癌に強く反応し，正常の腎組織 の一部と移行上皮には弱く反応した。また子宮癌（7/7）胃癌（6/6）とも反応した。またリンパ節転移 移行上皮癌とも強く反応したが, 肉腫, リンパ腫, あるいは肝, 結腸, 膵, 食道の癌には反応しなかっ た. EH14は Western blot 解析にて分子量 $14 \mathrm{KD}$ と28KDの抗原を認識しており，ホルマリンやエタノー ルに安定であった。

EH14は，今までに報告された上皮特異抗原とは異なるものであり，移行上皮癌の組織学的検索に有用 であると考えられた。
}

キーワード：モノクローナル抗体, 移行上皮癌, 上皮膜抗原

緒

近年腫瘍免疫の発達, 特にモノクローナル抗体作製
により腫湯関連抗原の研究がさかんに行われるよらに なった。その中で移行上皮癌に対するモノクローナル 
抗体の作製も行われ, 1983年には Grossman ${ }^{1)}$ がはじめ て移行上皮癌に反応する抗体を報告し，また他にも散

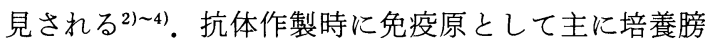
胼癌細胞や新鮮膀脱癌細胞を用いるが，よい抗体を求 めるには抗体産生ハイブリドーマの選択方法が問題と なる，今回われわれは，腎孟腫瘍（移行上皮癌 G2）を 免疫原として，マウスハイブリドーマを作製して，ス クリーニングとして, 移行上皮癌に反応し正常腎に反 応しないモノクローナル抗体 EH14を得，その特異性 を検討したので報告する。

\section{対象と方法}

1）マウスの免疫とハイブリドーマのスクリーニン グ

腎孟癌手術摘出標本を直ちに $4{ }^{\circ} \mathrm{C}$ の RPMI-1640に 容れ癌と正常腎を分離した。ついでそれぞれの組織を $0.5 \mathrm{mM}$ Phenylmethlsulfonyl flouride 入り $10 \mathrm{mM}$ リ ン酸緩衝生理食塩液（PBS）にて $100 \mathrm{mg} / \mathrm{ml}$ の濃度と し,ホモジナイザーにて細胞を破壊し, $-80^{\circ} \mathrm{C}$ に保存 した。

免疫方法は，まず移行上皮癌と Freund complete adjuvant (GIBCO Lab.) とをシセル化し BALB/c マ ウスに腹腔内注射で， 2 週間間隔で $3 \sim 4$ 回行った。 最終免疫は移行上皮癌のみを $10 \mathrm{mg}$ 静脈内投与した。 その 2 日後にマウスの脾臓を摘出し, 脾生細胞を得た. 一方マウス骨髄腫細胞はNS/1を用い, Kohler と Milstein ${ }^{5)}$ の方法に準じて細胞融合を行った。

第一次スクリーニングとして，二トロセルロース膜 上において Dot blot ELISA を用いた。簡単に述べる と, まず凍結保存していた膀胖癌細胞および腎細胞の ホモジネイトを96穴 Biodot (ATTO Corporation)を

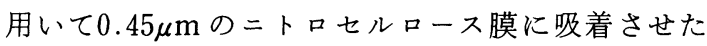
後, 1 \%bovine serum albumin(BSA)-PBS で膜の非 特異的吸着をブロックした。ハイブリドーマ・コロニー 培養上清を $100 \mu \mathrm{l} / \mathrm{dot}$ 添加し, 室温, 1 時間インキュ ベートした。 その後ペルオキシダーゼ標識抗マウス $\operatorname{IgG}$ および IgM 山羊抗体 (TAGO inc.) と室温, 1 時 間インキュベートし，十分洗浄したのち，ペルオキシ ダーゼの基質溶液4-chloro-1-naphthol- $\mathrm{H}_{2} \mathrm{O}_{2}$ を加光青 色に呈色した培養上清を陽性とした。そこで膀胼癌は 陽性, 正常腎細胞が陰性のコロニーが求めるものであ り，限界希釈法にてモノクローナル抗体産生クローン を得た。

2）モノクローナル抗体の精製

クローン化されたハイブリドーマ（ $5 \times 10^{6}$ 個）をあ
らかじめプリスタン投与された $\mathrm{BALB} / \mathrm{c}$ マウスの腹 腔内でさらに增殖させ，腹水を採取し，40\%硫安塩析 法6) にて抗体分画を沈澱させ，0.01M PBS に溶解させ た。この溶解液は液体クロマトグラフィー（FPLC, Pharmacia）にて1つの分画であることが確かめられ た。抗体蛋白量は lowry 法》にとて測定した。

モノクローナル抗体のタイピングは Mouse monoclonal antibody isotyping kit (Amersham International plc.) を使用した.

3) 免疫組織学的検討

手術時摘出標本を凍結切片拈よびェタノール固定と $10 \%$ ホルマリン固定後パラフィン包埋切片を作製し た. 脱バラしたのち, それぞれの切片を酵素抗体 avidin-biotin-peroxidase complex method (ABC 法) ${ }^{18)}$ とて行なった.

簡単に述べると，まず切片を内因性ペルオキシダー ゼをブロックするため, $0.3 \%$ 過酸化水素入りメタョー ルにて30分間インキュベートした. PBSで十分に洗浄 したあと非特異的反応をブロックするため PBS-BSA （1\%）で 1 時間室温にてインキュベートした。第 1 次 抗体は EH14と E29 (DAKOPATTS a/s No. M613) を用い室温にて 1 時間反応させた. PBS で十分に洗浄 したあと EH14に対しては抗 IgM Kit（Vector）を, E29に対しては IgG Kit (Vector)を用いて ABC 法を 行った. $\mathrm{DAB}$ (3,3'-Diaminoben zidine) 反応は 2 分間 とした。また核染色は Mayerのへマトキシリン液に て 5 分間行った。

\section{4) Western blot 解析}

モノクローナル抗体の認識抗原の分子量の決定は Western blot 解析法にて行った. 移行上皮癌をク口ロ フォルム抽出法にて糖タンパクを分離した。 簡単に述 べると，まず腫瘍を $100 \mathrm{mg} / \mathrm{ml}$ の濃度でホモジネイト した、このサンプル $0.1 \mathrm{ml}$ と $0.4 \mathrm{ml}$ のメタノールとを 混合し，次いで $0.1 \mathrm{ml}$ のクロロフォルムを加光，また $0.3 \mathrm{ml}$ の水で十分に振盪したのち $10,000 \mathrm{~g}$ にて 1 分遠 沈した。 上清を捨てたのち0.3mlのメタノールを混合 し $10,000 \mathrm{~g}$ にて 2 分遠沈し沈澱物を得た。これを $2 \%$ sodium dodesyl sulfate（SDS）を含む0.0625Mトリ ス一塩酸 Buffer に溶解し, グラジェントゲル SDSPAG プレート10/20 (第一化学薬品)を用いて電気泳 動を行った，その後ニトロセルロース膜に移行させ ${ }^{8)}$, PBS-BSA でブロッキングしたあと, EH14を反応させ た。十分に洗浄したあとニトロセルロース膜を山羊抗 マウス IgM（TAGO inc.) にて反応させ，DAB 液に 
て染色を行った。またマーカーはコマジンブルー染色 を行った。

\section{結果}

ハイブリドーマの選択では, Fig. 1 にあるように Dot blots ELISA にて腫瘍に反応し，腎に反応しない

Fig. 1

$\mathrm{T}$ : Transitional cell carcinoma, NK : Normal kidney tissue, $\mathrm{C}:$ Control

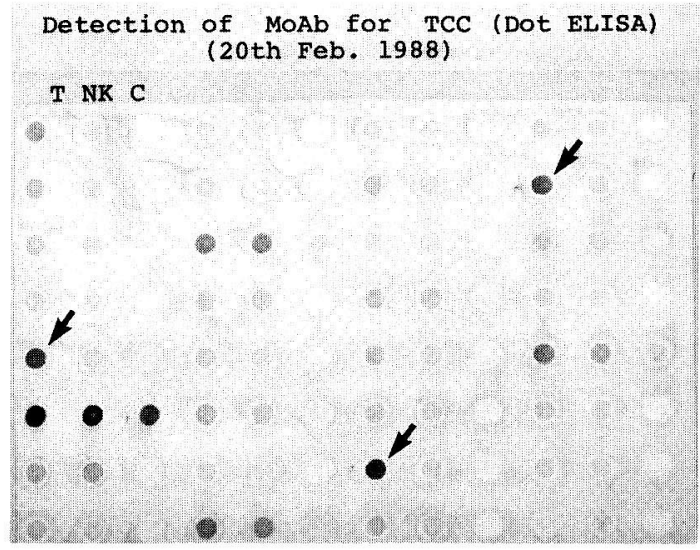

Fig. 2 Western blot analysis 1: Maker, 2: Transitional cell carcinoma (TCC) G2, 3 : TCC G3, 4 : TCC G1

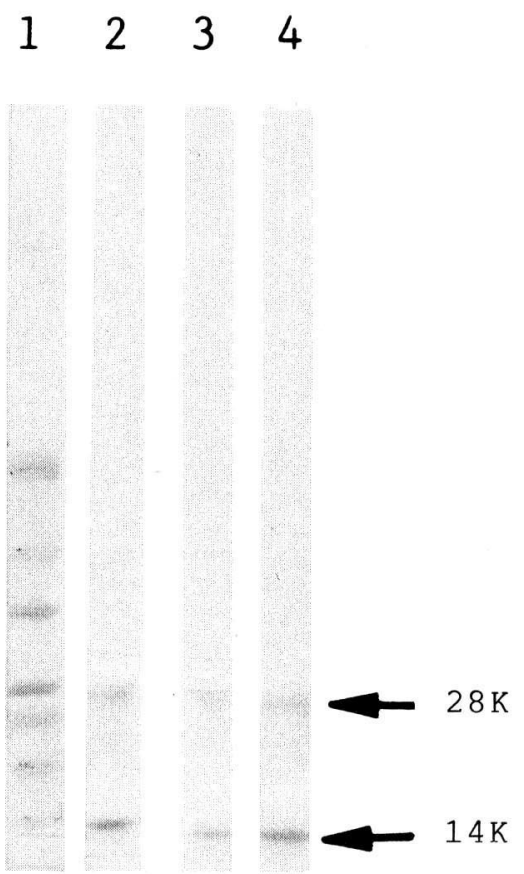

クローン（】）を選択した，次いで膀脱癌組織を $\mathrm{ABC}$ 法にて染色し, 膀胱癌と反応するモノクローナル抗体 EH14を選択抒よび精製した。EH14のサブクラスは IgM kappa type であった. Fig. 2 は Western blot解 析の結果を示したものである.No. 1はマーカーであ るNo. 2 4は移行上皮癌から得られたペレットであ るが，14KD と28KDにバンドが認められた。

免疫組織学的検索では，Fig. 3 に示すように，移行 上皮癌は, 粘膜下層に浸潤している腫瘍細胞も含めて

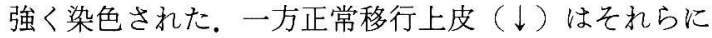
比し弱く染色された. Fig. 4 は移行上皮癌 (G3) の E29(左), EH14(右)の染色性を比較したものである. E29に比べEH14は腫瘍全体に強く染色されているこ とがわかる. Table 1 は, EH14ですべて強陽性に反応 した移行上皮癌 22 症例 $(\mathrm{G} 1 ： 3$ 例, G2：4 例, G3：15 例)に打けるE29の反応性を示したものである。強陽性 は 1 例，陽性は 4 例であり，移行上皮癌に対し EH14は E29より強い親和性が認められた。 また, Grade 間で反 応の強度は無関係であった. Fig. 5 は移行上皮癌 $(\mathrm{G} 3)$ のリンパ節転移像である。左はへマトキシリン・エオ ジン染色であり，右は EH14による染色である。腫湟は 全て茶褐色で染色され転移巣は一目瞭然である. Fig. 6 は膀胱癌の肝転移巣であるが，肝組織等は染色され ず移行上皮癌のみが染色された。

Table 2 は種々の腫瘍について EH14との反応を検 討したものである.移行上皮癌は29例(G1：4 例, G2： 6 例， G3：19例）すべて強陽性（\#）であり Gradeに 関係なく染色された。その法か子宮癌, 胃癌, 前立腺 癌, 胎児性癌, 卵巣癌, 皮虐癌 (扁平上皮癌) は, 移 行上皮癌汪どではないが, すべて陽性であるのに対し， 膵癌, 食道癌, 結腸癌, 甲状腺癌, 肉腫, リンパ腫, 神経腫瘍は染色されなかった。

正常臓器に対する反応性を Table 3 に示したが膀 脱移行上皮, 気管上皮, 子宮扁平上皮, 皮膚が陽性 $(+)$

Table 1 Reactivity of E29 to transitional cell carcinoma on immunohistochemistry

\begin{tabular}{cc}
\hline Reactivity & Number of cases \\
\hline$H$ & $1^{*}$ \\
+ & 4 \\
\pm & 11 \\
- & 6 \\
& Total 22 \\
\hline
\end{tabular}

*All tumors were strongly stained with EH14. 
Fig. 3 移行上皮癌 $(\mathrm{G} 2 \sim 3)$ と正常膀羘上皮との反応. 移行上皮癌とは強陽性像を示

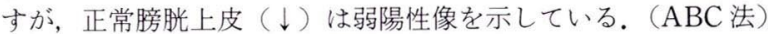

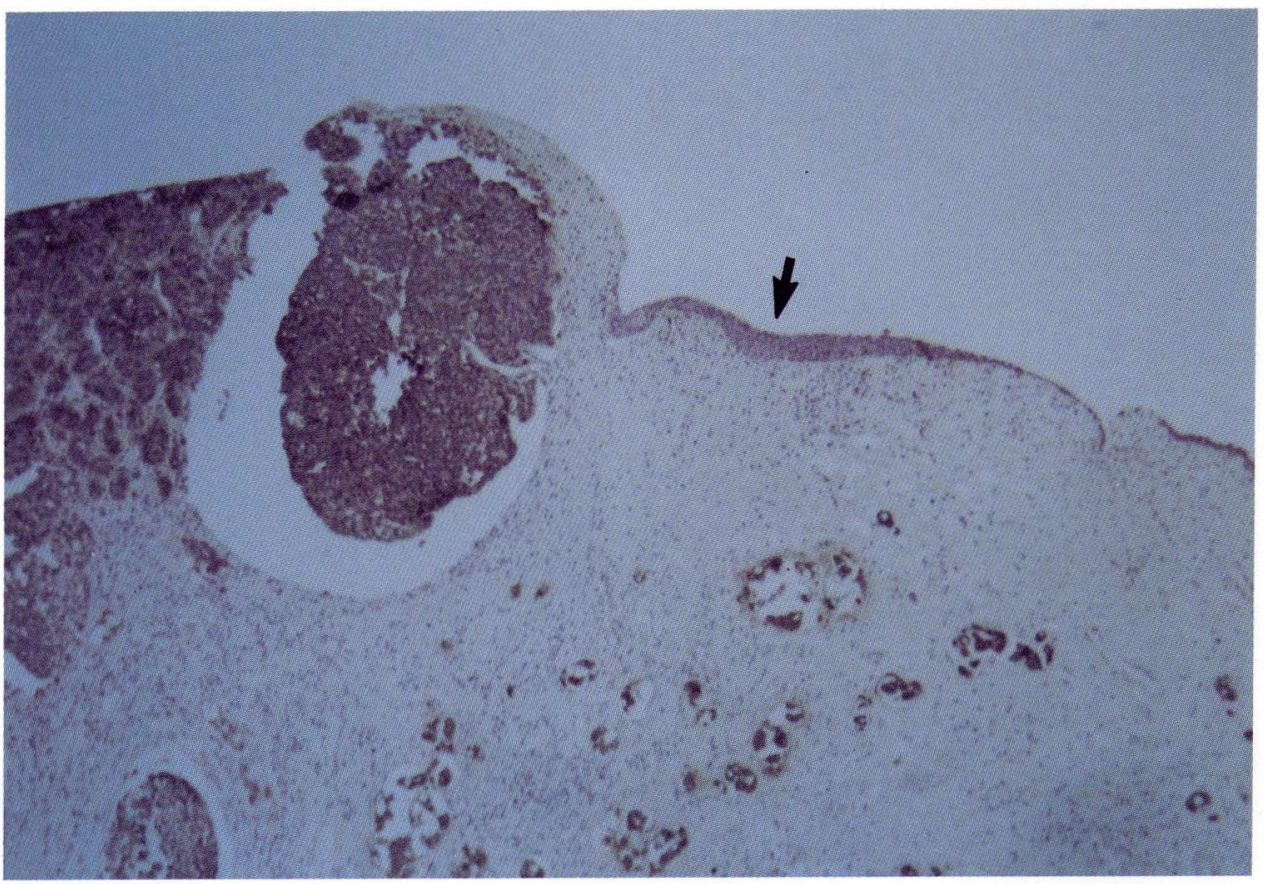

Fig. 4 移行上皮癌（G3）の反応，左はE29による染色で陽性像（十）．右はEH14に よる染色で強陽性像 (H).（ABC 法）
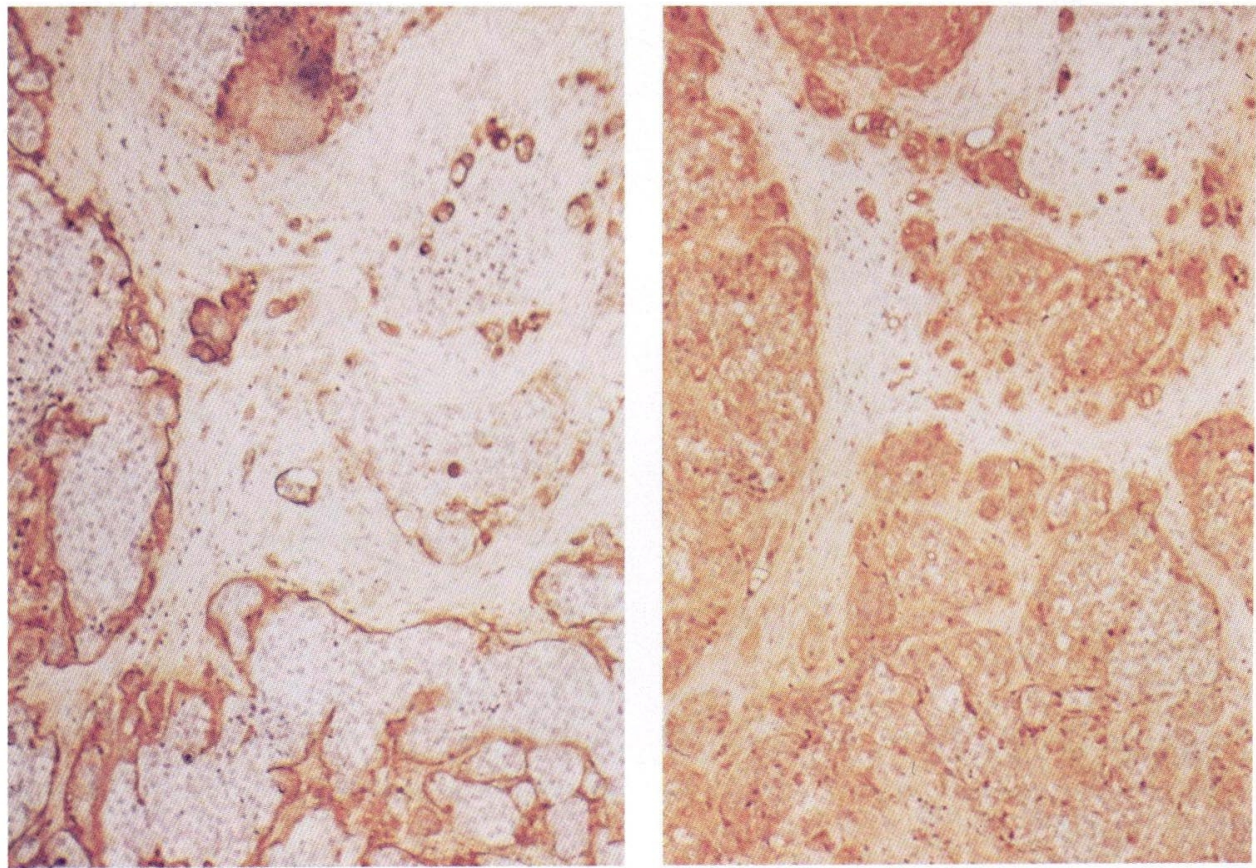
Fig. 5 移行上皮癌 (G3)の反応. 左はへマトキシリンェオジン染色. 右は EH14によ る染色. ( $\mathrm{ABC}$ 法)
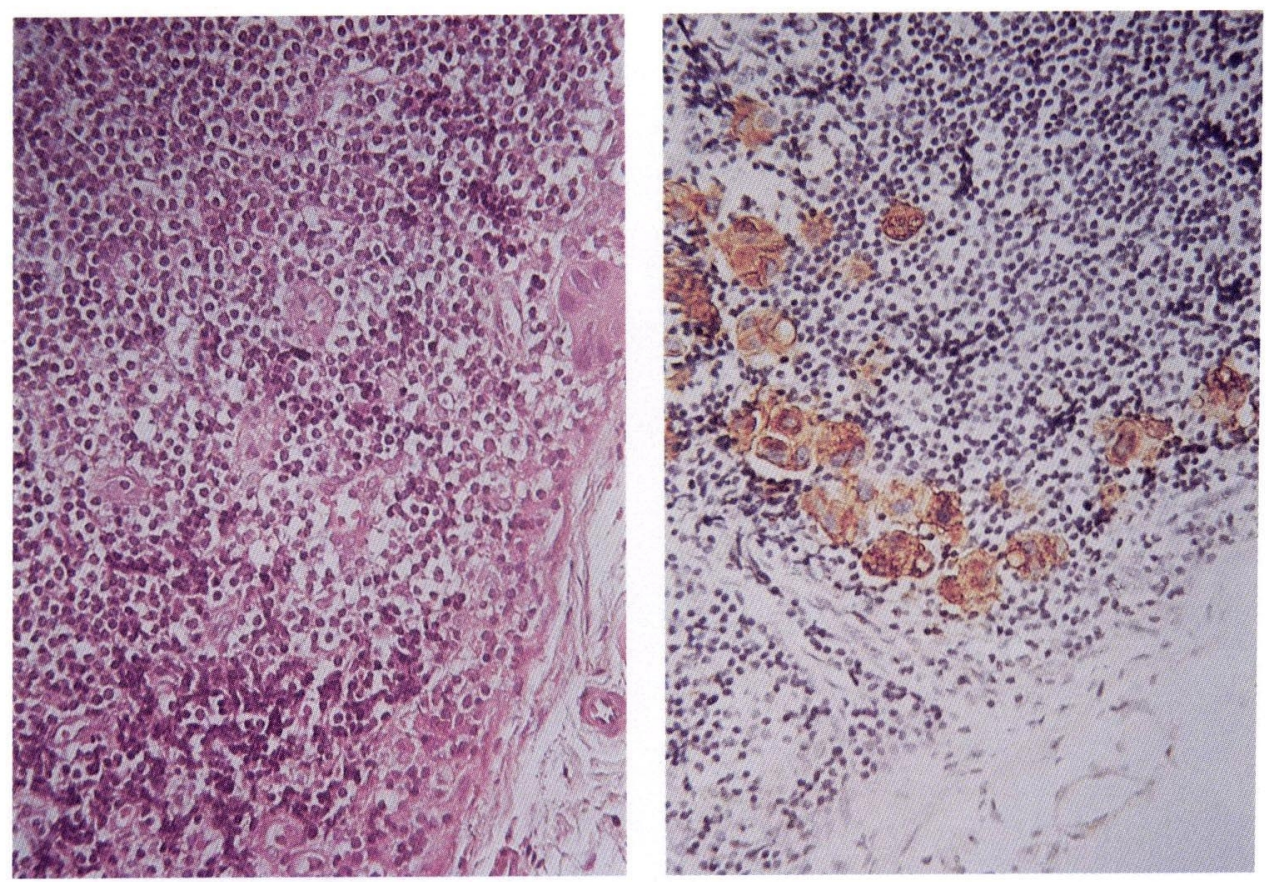

Fig. 6 移行上皮癌の肝転移像。（ABC 法）

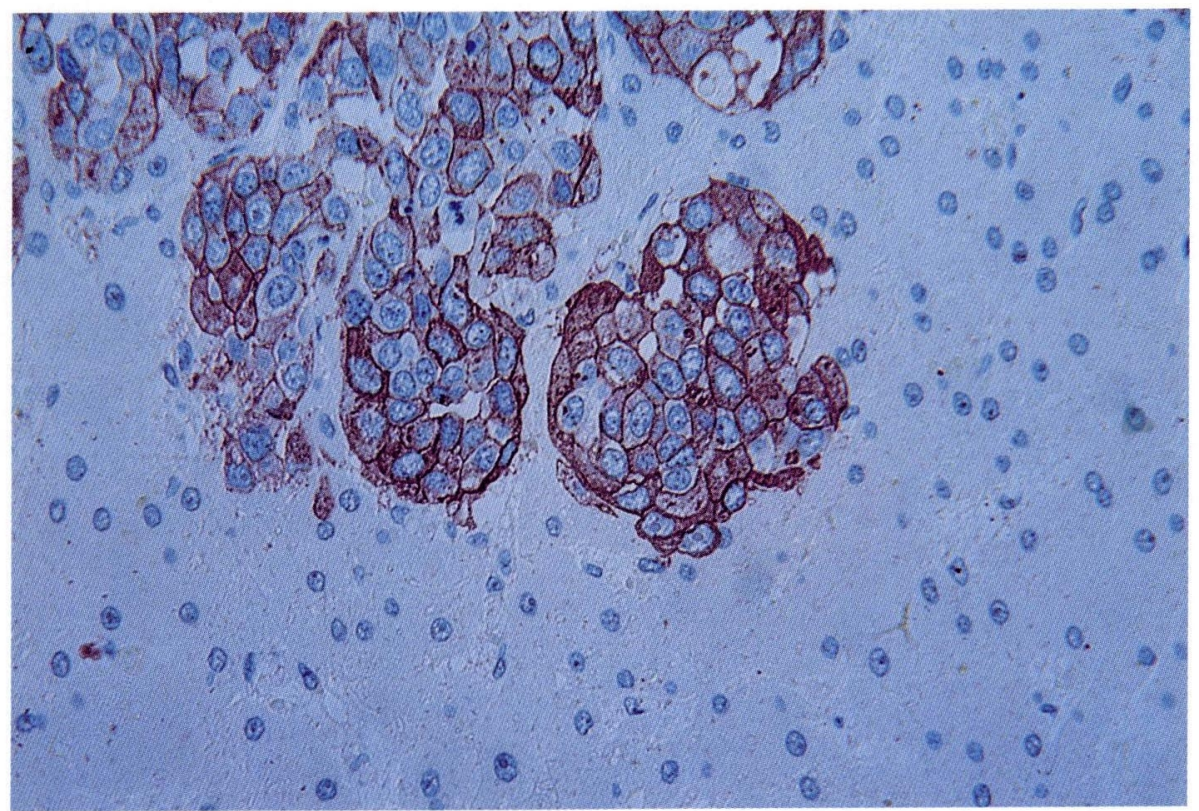


Table 2 Reactivity of EH14 with human tumors by immunoperoxidase staining (ABC method)

\begin{tabular}{lcl}
\hline \multicolumn{1}{c}{ Tumor } & Positive Rate & Reactivity \\
\hline Transitional cell carcinoma & $29 / 29$ & $\#^{* 1}$ \\
Uterus & $7 / 7$ & $+\sim \#$ \\
Lung & $2 / 2$ & \pm \\
Breast & $1 / 1$ & \pm \\
Stomach & $6 / 6$ & $+\sim \#$ \\
Prostate & $3 / 3$ & $\pm \sim \#$ \\
Skin & $1 / 1$ & + \\
Testicle(Embryonal Cell carcinoma) & $1 / 1$ & + \\
Ovary & $1 / 1$ & + \\
Pancreas & $0 / 2$ & \\
Esophagus & $0 / 2$ & \\
Colon & $0 / 2$ & \\
Liver & $0 / 2$ & \\
Thyroid & $0 / 2$ \\
Sarcoma & $0 / 6$ \\
Lymphoma & $0 / 4$ \\
Nerve & $0 / 2$ \\
\hline
\end{tabular}

*1 All tumor cells were strong stained.

Table 3 Reactivity of EH14 with human tissues by immunoperoxidase staining ( $\mathrm{ABC}$ method)

\begin{tabular}{lcc}
\hline \multicolumn{1}{c}{ Tissue } & Positive Rate & Reactivity \\
\hline Transitional cell & $5 / 5$ & $+^{* 1}$ \\
Bronchus & $3 / 3$ & + \\
Uterus & $4 / 4$ & + \\
Skin & $1 / 1$ & + \\
Kidney & $4 / 4$ & $\pm^{* 2}$ \\
Prostate & $3 / 6$ & \pm \\
Thyroid & $0 / 2$ & \\
Liver & $0 / 4$ & \\
Esophagus & $0 / 2$ & \\
Stomach & $4 / 5$ & \\
Adrenal gland & $0 / 2$ & \\
Cerebrum & $0 / 2$ & \\
Fetus ${ }^{* 3}$ & & \\
$\quad$ Kidney & $1 / 1$ & \pm \\
$\quad$ Stomach & $1 / 1$ & + \\
Testis & $1 / 1$ & \pm \\
Pancreas & $1 / 1$ & \pm \\
Adrenal & $0 / 1$ & \\
Liver & $0 / 1$ & \\
Brain & $0 / 1$ & \\
\hline
\end{tabular}

* 1 Only epithelial components were stained.

* 2 Occasionally a few areas of epithelial cells were stained.

* 3 25-week-old fetal tissues were used for the assays.
を示しまた腎や前立腺等は一部の上皮細胞のみが染 色された。25週の無脳症にて死亡した胎児の検討も 行ったが，成人と異なり胃上皮が陽性の所見を示し， 睪丸, 膵は一部のみが染色された。

\section{考察}

ある種の癌細胞には癌特異的抗原があるとの報告が ある。.上移行上皮癌の抗原性に関しては, 腫瘍の悪 性度の上昇にともない $\mathrm{ABH}$ 血液型抗原の消失するこ $亡^{9)}$, 癌化に伴い Thomsen-Friedenreich 抗原が出現 し10)，それが膀脱腫瘍の再発率に関係があること ${ }^{1112)}$ が報告されている．膀胱組織特異抗原の存在 ${ }^{10)}$ および 膀胱癌特異的ではないが関連抗原を認識するモノク ローナル抗体 ${ }^{3) 13}$ )の報告も散見される。また膀胱癌特 異抗原を認識することを示唆する抗体 ${ }^{4}$ の報告もなさ れている。

モノクローナル抗体を作製する場合，目的とする抗 原に特異性の高い抗体を産生するハイブリドーマのス クリーニングが極めて重要であり, HLA 抗原系や他 の抗原と交叉反応を除去するため, リンパ球を使って の ELISA 法あるいは組織学的に検索する方法が多く 用いられている. Schaerfe ら ${ }^{14)}$ は腎癌と正常腎とを木 モジネイトし，ELISA 法にてハイブリドーマを選択 し，腎癌に対するモノクローナル抗体を作製した。わ れわれは腎孟癌で移行上皮組織と腎組織を同時に用 い，前述した簡便なスクリーニング法にて移行上皮癌 に強く反応する $\mathrm{EH} 14$ を得ることができた。この手技 はスクリーニングの段階で極めて有用であると思われ た。

EH14では Fig. 3 に示したよらに正常移行上皮より 移行上皮癌が強く染色された。 また Table 1, 2 に示し たように膀胱癌ほど強くはないが，子宮癌や胃癌など とも反応した。 また正常扁平上皮や気管上皮にも反応 し，EH14は上皮特異抗原を認識しているように思わ れた。 上皮特異抗原に関しては, Hyderman らは人乳 の脂肪球被膜 (human milk fat globule mem-brane) から得られた乳腺上皮に存在する分子量 $50 \mathrm{KD}$ の glycoprotein epithelial mem-brane antigen (EMA) と名付けこれに対するモノクローナル抗体 E29が報告された ${ }^{1516)}$ ，そこでわれわれはこの抗体と 比較すべく免疫組織学的に検討したが, Fig. 4 に示す ように E29は膀胱腫瘍全体でなく，その細胞群周囲が 特に染色され，EH14とは異なるパターンであり，また Table 1 に示したように移行上皮癌でも染色されない ものも多かった。 また皮抗原として Keratin- 
Protein 報告されているが17)この分子量は40６7 $\mathrm{KD}$ であり, EH14の認識する抗原とは異なったもので ある。この抗原は移行上皮癌に強く表出されるもので あり，またホルマリンに対し安定であるため標本検索 に有用と考兄られた。

また，膀胱癌のリンパ節を14例について検討したと ころ, HE 染色で認められた転移巣はすべて強陽性に 染色され (Fig. 5), 微小リンパ節転移の検索にも有用 であると考えられた。

\section{結 語}

腎孟癌（移行上皮癌，G2）を抗原として得られたモ ノクローナル抗体 EH14について検討を行い, 以下の 如き結果を得た。

1）ハイブリドーマの選択時に移行上皮癌と同一患 者の正常腎組織を用い, Dot blots ELISA 法にてスク リーニングを行ったが，この方法は簡便かつ効率がょ いと思われた。

2) EH14は IgM kappa type で分子量 $14 \mathrm{KD}$ と28 KDの抗原を認識し，この抗原はホルマリンやエタ ノールに安定であった。

3）EH14は移行上皮癌29例全て強陽性を示し，また 正常移行上皮や扁平上皮とも陽性を示し上皮特異抗原 を認識する抗体と考えられた。

4）EH14は移行上皮癌の浸潤度およびリンパ節や 他藏器転移の検索に有用であると考えられた。

\section{文献}

1) Grossman, H.B.: Hybridoma antibodies reactive with human bladder carcinoma cell surface antigens. J. Urol., 130, 610-614, 1983.

2) Nathrath, W.B.J., Detheridge, F. and Franks, L. M.: Species cross-reacting epithelial and urothelial specific antigens in human fetal, adult and neoplastic bladder epithelium. J.N.C. I., 63, 1323-1327, 1979.

3) Fradet, Y., Cordon-Cardo, C., Thomsen, T., Daly, M.E., Whitmore, W.F. Jr., Lloydo, K.O., Melamed, M.R. and Old, L.J.: Cell surface antigens of human bladder cancer defined by mouse monoclonal antibodies. Proc. Natl. Acad. Sci. U.S.A., 81, 224-228, 1984.

4）高橋伸也, 高橋信好, 高橋浩一, 小泉幸弘, 川口俊 明, 富樫繁也, 鈴木唯司, 舟生富寿: 膀胱癌モノク ローナル抗体の研究。日泌尿会誌, 78, 791-801, 1987.

5) Kohler, G. and Milsterin, C.: Continous cultures of fused cells secreting antibody of predefined specificity. Nature, 256, 494-497,
1975.

6）中村 弘, 杉浦 勉: 抗体の精製とクラスの分画. 免疫生化学研究法. p. 11-17, 1986.

7) Lowry, O.H., Rosebrough, M.J., Farr, A.L. and Randall, R.J.: Protein measurement with the folin phenol reagent. J. Biol. Chem., 193, 749-767, 1951.

8) Towbin, H., Saehlin, T., Gordon, J.: Electrophoretic transfer of proteins from polyacrylamide gels to nitrocellulose sheets: Procedure and some applications. Proc. Natl. Acad. Sci. U.S.A., 76, 4350, 1979.

9) Limas, C. and Lange, P.: Altered reactivity for $\mathrm{A}, \mathrm{B}, \mathrm{H}$ antigens in transitional cell carcinoma of the urinary bladder. A study of the mechanisms involved. Cancer, 46, 1366-1373, 1980.

10) Coon, J.S., Weinstein, R.S. and Summers, J.L.: Blood group precursor $\mathrm{T}$-antigen expression in human urinary bladder carcinoma. Am. J. Clin. Pathol., 77, 692-699, 1982.

11) Yokoyama, M., Ohoka, H., Oda, H., Oda, T., Utsumi, S. and Takeuchi, M.: ThomsenFriedenreich antigen in bladder cancer tissues detected by monoclonal antibody. Acta Urol. Jpn., 34, 255-258, 1988.

12）織田英昭, 小田剛士, 横山雅好, 竹内正文, 大岡啓 二, 内海 爽: Thomsen-Friedenreich antigen $飞$ 対する monoclonal antibody と soybean agglutinin による膀胼腫瘍抗原の検索. 日泌尿会誌, 79, 713-718, 1988.

13) Young, D.A., Prout, G.R. and Lin, C.W.: Production and characterization of mouse monoclonal antibodies to human bladder tumorassociated antigens. Cancer Res., 45, 4439 $-4446,1985$.

14) Schaerfe, T., Becht, E., Kaltwasser, R., Thueroff, J.W., Jacobi, G.H. and Hohenfellner, R.: Tumor-specific monoclonal antibodies for renal cell carcinoma. Eur. Urol., 11, 117-120, 1985.

15) Hyderman, E., Steele, K. and Ormerod, M.G. : A new antigen on the epithelial membrane: Its immunoperoxidase localisation in normal and neoplastic tissues. J. Clin. Pathol., 32, 35-39, 1979.

16) Hyderman, E., Strudley, I., Powell, G., Richardson, T.C., Cordell, J.L. and Mason, D.Y.: A new moncoclonal antibody to epithelial membrane antigen (EMA)-E29. A comparison of its immunocytochemical reactivity with polyclonal anto-EMA antibodies and with another monoclonal antibody, HMFG-2. Br. J. Cancer, 
52, 355-361, 1985.

17) Pinkus, G., Ehteridge, C.L. and O'connor, E.M. : Are keratin proteins a better tumor marker than epithelial membrane antigen? Am. J. Clin. Pathol., 85, 269-277, 1986.

18) Hsu, S.M., Raine, L. and Fanger, H.: Use of auidin-biotin-peroxidase complex $(A B C)$ in immunoperoxidase techniques: A comparison between $A B C$ and unlabeled antibody (PAP) procedures. J. Histochem. Cytochem., 29, 577-580, 1981. 